\title{
Synchronous testicular liposarcoma and prostate adenocarcinoma: a case report
}

\author{
Umut Demirci', Suleyman Buyukberber ${ }^{1 *}$, Asli Cakir ${ }^{2}$, Banu Ozturk¹, Nalan Akyurek², Basak Unver ${ }^{1}$, Meltem Baykara $^{1}$ \\ , Mustafa Benekli', Ugur Coskun ${ }^{1}$
}

\begin{abstract}
Prostate adenocarcinoma is the most common malignancy and the second leading cause of cancer related deaths in men. Testicular liposarcomas are uncommon soft tissue neoplasms. We report coexistence of prostate cancer and testicular liposarcoma in a 69 year-old-man because while orchiectomy endications are decreasing day by day, these second malignancies should not be missed.
\end{abstract}

\section{Introduction}

Prostate adenocarcinoma is the most common malignancy in men and also the leading cause of cancer related death. Sarcomas of the genitourinary tract account for $5 \%$ of these cases and $2 \%$ of all urological tumors. The testis is the most commonly involved urological site and accounts for approximately $30 \%$ of all genitourinary sarcomas [1].

Testicular liposarcomas are uncommon soft tissue neoplasms. Liposarcomas, account for $20-50 \%$ of sarcomas, seen in the paratesticular region [2,3]. Preoperative diagnosis is infrequent, these tumours sometimes present in elderly adults with a palpable mass of the inguinal canal or scrotum. These tumours may arise from the spermatic cord, fatty tissue or malignant transformation of a pre-existing lipoma [4]. Three pathologic categories of liposarcoma are recognized; well differentiated, myxoid/round cell and pleomorphic. Most paratesticular liposarcomas are well differentiated [5,6]. They frequently have a good prognosis because of their low grade of malignancy [7].

The relative rarity of adult testicular sarcomas has meant that the information used to guide treatment is based on previous experiences from various groups of few patients. Treatment options have invariably been evaluated in previous studies $[8,9]$. It has a high rate of survival over 5 years [10].

\footnotetext{
* Correspondence: buyukberber@gazi.edu.tr
'Department of Medical Oncology Gazi University Medical Faculty, 06500,

* Correspondence: buyukberber@gazi.edu.tr
${ }^{1}$ Department of Medical Oncology Gazi University Medical Faculty, 06500, Beşevler, Ankara, Turkey
}

(c) 2010 Demirci et al; licensee BioMed Central Ltd. This is an Open Access article distributed under the terms of the Creative Commons

\section{Case presentation}

In 2005; during a 69-year-old Asian origin Turkish man's routine controls, elevated prostate spesific antigen (PSA) levels was determined. His prostate biopsy appointed as adenocarcinoma with a score of Gleason 2 +3 (Figure 1). He has type II diabetes mellitus and hypertension. There was no attribute in his family story and systemic investigation. An abdominal CT scan evaluated prostate's dimensions as $47 \times 37 \times 33 \mathrm{~mm}$ and no additional pathological evidance was determined. In bone scan imaging, increased uptake of right tenth rib and left seventh rib were interpreted as malignancy. It was accepted as stage IV prostate carcinoma and radical orchiectomy was applied. In its microscopic investigation where left testis was normal, low grade liposarcoma was appointed in right testis (Figure 2).

In computed tomography scan of chest, no positive finding was determined. Radiation theraphy with $70 \mathrm{~Gy}$ was employed to prostate between July-September 2006. Because of obtaining synchroneous liposarcoma, adjuvant systemic therapy was given as four cure of IMA (Adriamycin $\left(60 \mathrm{mg} / \mathrm{m}^{2}\right) 1^{\text {st }}$, İfosfamide $\left(2.5 \mathrm{~g} / \mathrm{m}^{2}\right) 1^{\text {st }}$, $2^{\text {nd }}, 3^{\text {rd }}$, Mesna $\left(2.5 \mathrm{~g} / \mathrm{m}^{2}\right) 1^{\text {st }}, 2^{\text {nd }}, 3^{\text {rd }}$ days of every 21 day) in October-December 2006. In September 2008, his PSA and fPSA levels were $<0.002$ and no differentiation was determined in bone scan imaging.

\section{Discussion}

In recent years, hormone therapy (ADT) has been more choosen than surgical treatment for hormonal deprivation. Like our case; the second and important malignencies could be missed. While orchiectomy endications are

\section{1}




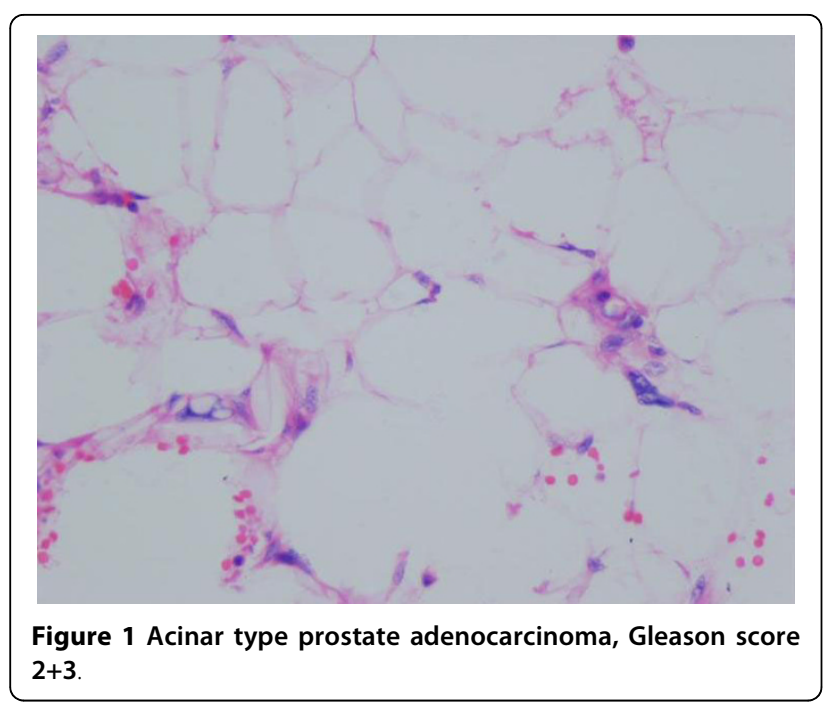

decreasing day by day, these second malignancies should not be missed. Our purposes in this case are to show the coexistence of prostate cancer and rare testicular neoplasm 'liposarcoma' and evaluate the treatment with literature.

The current guidelines recommends castration alone with either an orchiectomy or LHRH agonists. Patients with widely advanced and metastatic prostate cancer were previously treated with bilateral orchiectomy. Since the introduction of LHRH agonist therapy, surgical intervention has been practiced less often [11]. In our case if medical hormonal therapy was chosen, the diagnose of liposarcoma would be determined later.

A recent meta-analysis included 22 trials with 5710 advanced prostate cancer patients, applied both medical castration and bilateral orchiectomy or one of them alone. Statistically no significant survival advantage was

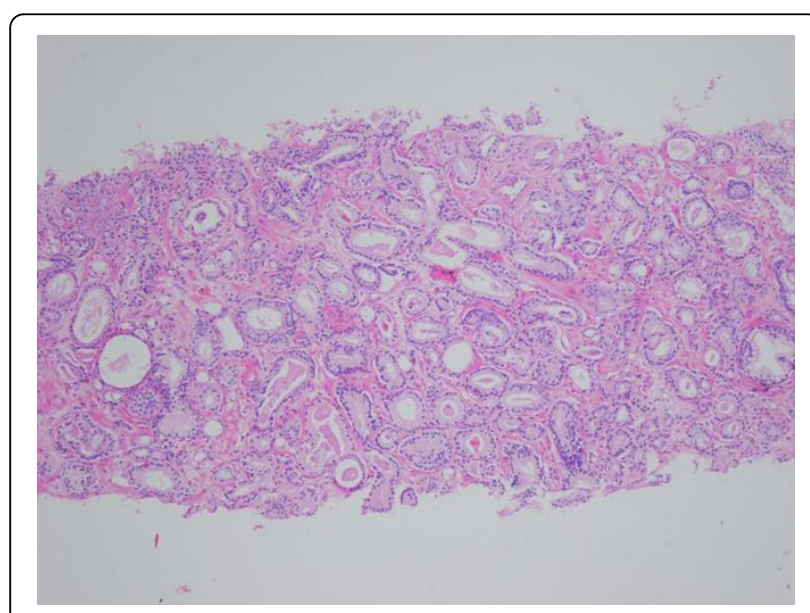

Figure 2 Atypic lypoblasts, propelled to edge nucleusus with vesicular and notched cytoplasm $(\mathrm{HE} \times 40)$. found with combined androgen blockage [12]. Although ADT is associated with high responses, its curative potential is limited and unfortunately nearly all patients develop resistance to hormonal therapy. In a study, 938 locally advanced or asymptomatic metastatic prostate cancer patients received treatment with orchiectomy or LHRH agonist either immediately or after symptoms occurred. Development of disease releated event was twice as common in the deferredtreatment group [13].

Testicular liposarcomas are uncommon cases in the literature. Its coexistence with another malignancy is rare. Although prostate cancer patients have higher risk of a second cancer than general population. The most frequently observed second malignancies in prostate cancer patients include carcinomas of the bladder, stomach, colon and lesser cutaneous and hematolymphoid malignancies The cause of death was always from the second neoplasia [14-16]. In 312 prostate cancer patients, 60 multiple malignant neoplasms (MMNs) was diagnosed. In 13 of them, prostate cancer and other malignancies were diagnosed simultaneously [17]. Another study with 392 patients who were treated for urologic cancers, 42 cases diagnosed with MMNs and only 16 patients (35\%) had synchronous MMNs. The incidence of prostatic cancer was higher than other single MMNs associated with genitourinary organs. In this study, the incidence of MMNs with genitourinary cancer was as high as $10.6 \%$ and the prognosis of these patients was poor [18]. In 397 patients with urinary system tumors, second malignancy were determined in 29 patients (6.6\%) and 21 of them had urological malignancy with the incidence of $6.1 \%$. Another current study follows up with 983 patients who were diagnosed as prostate cancer and whom 106 (11.5\%) developed a MMN for sixteen years. Uriary bladder cancer and malignant lymphoma occured in these patients [19].

In our case because liposarcoma was determined after radical orchiectomy, we decided the treatment choice as radiotherapy and four cycles of IMA as a chemotherapy regiment. The optimum local and systemic treatment for these tumours remains controversial, but there is a general consensus that all testicular sarcomas in adults should be managed with radical orchiectomy. Adjuvant locoregional radiation and/or chemotherapy apparently diminishes the risk of local relaps $[8,9,20]$.

\section{Consent}

Written informed consent was obtained from the patient for publication of this case report and any images. A copy of the written consent is available for review by the editor-in-Chief of this journal. 


\section{Author details}

${ }^{1}$ Department of Medical Oncology Gazi University Medical Faculty, 06500, Beşevler, Ankara, Turkey. ${ }^{2}$ Department of Pathology Gazi University Medical Faculty, 06500, Beşevler, Ankara, Turkey.

\section{Authors' contributions}

UD conceived the study. AC, BO, NA, BU, MB and UC performed the literature review. UD, and SB edit and coordinated the manuscript. All authors read and approved the final manuscript.

\section{Competing interests}

The authors declare that they have no competing interests.

Received: 6 November 2009

Accepted: 14 January 2010 Published: 14 January 2010

\section{References}

1. Frank I, Takahashi S, Tsukamoto T, Lieber MM: Genitourinary sarcomas and carcinosarcomas in adults. Comprehensive Textbook of Genitourinary Oncology Philadelphia: Lippincott Williams \& WilkinsVogelzang NJ, Shipley WU, Scardino PT, Coffey DS , 2 2000, 1110-1113.

2. Khoubehi B, Mishra V, Ali M, Motiwala H, Karim O: Adult paratesticular tumours. BJU International 2002, 90:707-715.

3. Coleman J, Brennan MF, Alektiar K, Russo P: Adult Spermatic Cord Sarcomas: Management and Results. Ann Surg Oncol 2003, 10:669-675.

4. Torosian MH, Wein AJ: Liposarcoma of the spermatic cord. Case report and review of literature. J Surg Oncol 1987, 34:179-181.

5. Mentzel T, Fletcher CD: Lipomatous tumours of soft tissues: an update. Virchows Arch 1995, 427:353-363.

6. Dei Tos AP, Dal Cin P: The role of cytogenetics in classification of soft tissue tumours. Virchows Arch 1997, 431:83-94.

7. Lewis JJ, Leung D, Woodruff JM, Brennan MF: Retroperitoneal soft-tissue sarcoma: analysis of 500 patients treated and followed at a single institution. Ann Surg 1998, 228:355-365.

8. Catton CN, Cummings BJ, Fornasier V, O'Sullivan B, Quirt I, Warr D: Adult paratesticular sarcomas. A review of 21 cases. J Urol 1991, 146:342-345.

9. Catton CN, Jewett M, O'Sullivan I, Kandel R: Paratesticular sarcoma: Failure pattern after definitive local therapy. J Urol 1999, 161:1844-1847.

10. Soler Soler JL, Zuluaga Gomez A, Hidalgo Domínguez MR, Bados Nieto MP, Martinez Torres JL, de la Fuente Serrano A, Nogueras Ocana M: Liposarcoma of the spermatic cord: a report of a new case and review of the literature. Actas Urol Esp 1999, 23:447-454.

11. Basch EM, Somerfield MR, Beer TM, Carducci MA, Higano CS, Hussain MH, Scher HI: American Society of Clinical Oncology endorsement of the Cancer Care Ontario Practice Guideline on nonhormonal therapy for men with metastatic hormone-refractory (castration-resistant) prostate cancer. American Society of Clinical Oncology. J Clin Oncol 2007, 25:5313-5318

12. Prostate Cancer Trialists: Collaborative Group. Maximum androgen blockade in advanced prostate cancer: an overview of the randomised trials. Lancet 2000, 355:1491-1498.

13. Medical Research Council Prostate Cancer Working Party Investigators Group: Immediate versus deferred treatment for advanced prostatic cancer: initial results of the Medical Research Council Trial. Br J Urol 1997, 79:235-246.

14. Pawlish KS, Schottenfeld D, Severson R, Montie JE: Risk of multiple primary cancers in prostate cancer patients in the Detroit metropolitan area: a retrospective cohort study. Prostate 1997, 33:75-86.

15. Boorjian S, Cowan JE, Konety BR, DuChane J, Tewari A, Carroll PR, Kane CJ: Bladder Cancer Incidence and Risk Factors in Men With Prostate Cancer: Results From Cancer of the Prostate Strategic Urologic Research Endeavor. J Urol 2007, 177:883-887.

16. Kellen E, Zeegers MP, Dirx M, Houterman S, Droste J, Lawrence G, Truyers C, Bruckers $L$, Molenberghs $G$, Joniau S, Buntinx F: Occurrence of both bladder and prostate cancer in five cancer registries in Belgium, The Netherlands and the United Kingdom. Eur J Cancer 2007, 43:1694-1700.

17. Kawakami S, Fukui I, Yonese J, Ueda T, Ohno Y, Tsuzuki M, Kawai T: Multiple primary malignant neoplasms associated with prostate cancer in 312 consecutive cases. Urol Int 1997, 59:243-247.
18. Fukagai T, Ishihara M, Funabashi K, Naitoh Y, Maruyama K: Multiple primary malignant neoplasms associated with genitourinary cancer. Hinyokika Kiyo 1996, 42:181-185.

19. Sugiyama T, Park YC, Iguchi M, Kurita T, Kiyo Hinyokika: Double cancer in urology. Hinyokika Kiyo 1984, 30:1427-1431.

20. Fagundes MA, Zietman AL, Althausen AF, Coen J, Shipley WU: The management of spermatic cord sarcoma. Cancer 1996, 77:1873-1187.

doi:10.1186/1757-1626-3-27

Cite this article as: Demirci et al:: Synchronous testicular liposarcoma and prostate adenocarcinoma: a case report. Cases Journal 2010 3:27.

\section{Publish with BioMed Central and every scientist can read your work free of charge}

"BioMed Central will be the most significant development for disseminating the results of biomedical research in our lifetime. "

Sir Paul Nurse, Cancer Research UK

Your research papers will be:

- available free of charge to the entire biomedical community

- peer reviewed and published immediately upon acceptance

- cited in PubMed and archived on PubMed Central

- yours - you keep the copyright 